\title{
Mediterranean Diet and Gene-Mediterranean Diet Interactions in Determining Intermediate Cardiovascular Disease Phenotypes
}

\author{
Mercedes Sotos Prieto \\ University of Valencia, Department of Preventive Medicine and Public Health and \\ CIBER Fisiopatología de la Obesidad y Nutrición, \\ Spain
}

\section{Introduction}

Currently, cardiovascular diseases (CVD) are one of the most important problems in the world. In fact, CVD are the first cause of death all over the world and, according to the World Health Organization (WHO), it is expected to remain so over coming years due to aging population and the increase of prevalence of CVD in countries with fewer resources.

According to European statistics, 2008 for CVD, the leading causes of death in Europe are coronary heart disease and stroke. In Europe, deaths from these diseases are 4.3 million each year. Nearly half $(48 \%)$ of all deaths are due to CVD (54\% of deaths in women and $43 \%$ of deaths in men). Regional variations in cardiovascular mortality have been observed both between and within countries in Europe (Sans et al., 1997; Müller et al., 2004). Coronary heart disease mortality patterns showed a clear north-east to south-west gradient in CVD mortality (1990-1992; 45-74 years age-adjusted) with the lowest rates for both men and women in France, Spain, Switzerland, and Italy (Sans et al., 1997). Many factors could be related to the different distribution (eating behaviours, life style, and genetics).

To begin with the development of this chapter it is necessary to consider firstly the health determinants to better understand and focus the aim of this chapter.

The model of health fields proposed by Laframboise in 1973 and developed in Lalonde Report in 1974 (Lalonde 1974) has revolutionized contemporary public health due to the approaching and explaining of the health levels in the populations and therefore, the way of formulating health policies. Marc Lalonde proposed a new "health field" concept that can be broken up into four broad elements: Human biology, Environment, Lifestyle, and Health Care Organization".

Of the four determinants of health, the one which is most susceptible to be modified is lifestyle. Apart from not smoking, the most important lifestyle determinants of good health are what we eat and how active we are. A healthy diet helps to maintain or improve our health. However, as we said before, the CVD are increasing all over the word, and authorities view it as one of the most serious Public Health problems in the 21st century. 
CVD are complex and the risk factors that contribute to the development of CVD can be classified into different categories depending on whether they are modified or not (Posner et al., 1991, Haskell et al., 2003) and how they contribute to the development of CVD (Linton et al., 2003). Thus, on the one hand, we have not modifiable factors such as age, sex, family history and genetics. With regard to genetics, we inherit the genetic risk to develop CVD, but this risk can be modulated by other modifiable factors. In this chapter we will deeply discuss the relation between genes and environmental factors (especially diet) in the prevention of CVD (Figure 1).

On the other hand, we also have factors that are susceptible to be modified such as cholesterol concentrations, hypertension, smoking, diabetes, type of diet, obesity, sedentary lifestyle, stress and consumption of oral contraceptives. The more risk factors a person has, the higher risk of developing CVD. Some risk factors can be changed, treated or modified, and some others not. But controlling the largest possible number of risk factors through changes in lifestyle and/or drugs can reduce cardiovascular risk. Among the environmental factors associated with CVD, and as a part of one of the health determinants proposed by Lalonde, diet has a great impact on lipid metabolism, oxidative stress and the development of the atherosclerotic process (Ordovas et al., 2004) (Figure 1). Changes in eating behaviours have contributed to the growing epidemic of chronic diseases. These changes are characterized by an unbalanced diet consisting of food with a high density of energy rich in saturated fatty acids (SAF) as well as a decrease in physical activity. This process is called nutritional transition. Given these facts, researchers are trying to elucidate the best diet to prevent CVD. However, there is a widespread of controversy. Different proposals have been considered such as low-fat diet, diet low in carbohydrates and high in proteins, among others, all promoted by the acquisition of knowledge, fashion or business interests (Ordovas et al., 2004).

Traditionally, the American Heart Association (AHA) has based dietary recommendations for primary care of cardiovascular risk in a low-fat diet (Krauss MR et al, 2000). This diet is also based on reducing all types of fat so that the contribution of total fat calories should be less than $30 \%$ (of which SAF are less than 10\%) and cholesterol intake less than $300 \mathrm{mg}$ daily. This type of diet causes a decrease in total cholesterol (TC) and LDL-C, and a decrease or not variation in HDL-C and increases or unchanged triglycerides (TG) concentrations (Obarzanek et al., 2001; Lichtensein et al., 2002, Howard et al., 2006). Later on, in 2005, a new version of USDA pyramid in which food groups are presented in vertical and which incorporates the concept that the diet should be tailored to individual needs came up (USDA, 2005).

After the AHA recommendations, other types of diets have been proposed such as diets rich in protein, low carb, Mediterranean diet, etc. Mediterranean diet has attracted the most interest by its great relevance regarding the protective role in primary and secondary care of CVD.

The aim of this chapter is to analyse the role of the Mediterranean diet in determining intermediate CVD phenotypes. We also review one of the most emerging topics currently: the role of gene-Mediterranean diet interactions on CVD.

\section{Mediterranean diet}

Due to the great incidence of CVD, Mediterranean diet has gained a considerable popularity during the last decades. The Mediterranean area is a sociocultural construction built on the 
countries bordering the Mediterranean Sea. Food habits have been consolidated over the centuries and are the result of geographical and climatic factors, as well as cultural, political and religious factors of Mediterranean people. Mediterranean area is identified by characteristics based on agriculture (natural grain, olives, wine and vegetables), fishing and consumption of poultry instead of other meats.

Furthermore, Mediterranean diet includes food and cooking techniques typical of Mediterranean countries which have been gradually abandoned by western patterns.

The Mediterranean diet has been described as a model from a nutritional point of view due to the good balance that provides its food items (micronutrients, vitamins, antioxidants). Nevertheless, as well as the cooking techniques have been abandoned, in the last few years changes in lifestyle have triggered a move away from the recommended intakes in relation to several nutrients. All these changes make it even more difficult to ensure adequate intakes of vitamins and minerals. This problem could affect more to certain risk groups such us women, the elderly, children, gestating and lactating women and ill people. Knowing the extent of this reality it seems worthy to inform people and society in general about the necessary changes in the diet and about the characteristics of the Mediterranean diet which are being lost and should be restored.

\subsection{Definition of the Mediterranean diet}

The concept of the Mediterranean diet originated from several observational studies in the 1950s, being the most known the Seven Countries Study initiated by Ancel Keys (Ancel Keys 1970). Subsequently, several studies have associated increased longevity, lower mortality and morbidity to Mediterranean diet (Keys et al., 1986; de Lorgeril et al., 1999; Singh et al., 2002; Trichopoulou et al., 2003; Knoops et al., 2004). Taken as a whole, these studies showed that, despite a high fat intake, these populations had low rates of coronary heart disease and other vascular diseases, cancer, inflammatory and degenerative diseases, resulting in a long life expectancy. The Mediterranean dietary pattern was considered to be largely responsible for the good health observed in these regions (Keys et al., 1986). Currently, there is a great number of clinical and epidemiological studies that have shown the benefits of the Mediterranean diet. However, these effects are attributed to the traditional Mediterranean diet and not to the Westernized patterns that nowadays characterize the South European countries (Serra-Majem et al., 2004).

Although there are several variations of the Mediterranean diet, the main characteristics include high consumption (daily consumption) of vegetables, fruit, whole grain cereals and low fat dairy products; weekly consumption of fish, poultry, tree nuts and legumes; relatively low consumption of red meat (approximately twice a month) as well as moderate daily consumption of alcohol (preferably in the form of wine) normally with meals (keys et al., 1986) (Figure 1).

Most of the articles published so far on Mediterranean diet are observational studies. However, there is a lack of intervention studies that demonstrate causal relationship. Although there are few randomized controlled trials of dietary intervention with Mediterranean Diet, we have recently strong data from one large randomize control trial supporting the beneficial effects of Mediterranean diet on CVD prevention (Estruch et al., 2006). 


\subsection{Principal studies that focus on Mediterranean diet and cardiovascular diseases}

In general, there is a predominance of observational studies related to Mediterranean Diet compared to clinical trials in the study of CVD. Thus, most of the studies are cross-sectional studies with a level III of evidence (based on the quality of evidence according to the 2nd edition of the U.S. Task Force (Harris et al., 2001)). The ATTICA study is the most remarkable (Pitsavos et al., 2003) and it was conducted on a representative sample of Greek men and women recruited from May 2001 to December 2002 in order to analyze cardiovascular risk factors, establish associations with lifestyle, socioeconomic factors, psychological characteristics, and assess their impact on CVD over a year, five and ten years. Several studies found a positive association between Mediterranean Diet and CVD (Tzima et al., 2007; Panagiotakos et al., 2006; Pitsavos et al., 2007).

Two other large European cohort studies (evidence level II-2) include the Greek cohort within EPIC (European Prospective Investigation into Cancer) (Trichopoulou et al., 2003, Slimani et al., 2002). They study the relationship between nutrition and cancer in 519,978 participants from 23 centers located in 20 European countries.

Another cohort study is the HALE (Knoops et al., 2004) (Healthy Ageing: Longitudinal Study in Europe). This project analyzed age-related changes and the determinants of healthy aging in terms of mortality and morbidity, and physical, mental, cognitive and social functionality in 13 European countries. Results from this study suggest that a high adherence to Mediterranean diet is associated with a reduction in both overall mortality and cardiovascular mortality.

Regarding intervention studies (level I of scientific evidence), two of the most known studies analyzing Mediterranean Diet are PREDIMED study (Prevention with Mediterranean diet) (Estruch et al., 2006) and Medi-RIVAGE study (Mediterranean Diet, Cardiovascular Risks and Gene Polymorphism) (Vincent-Baudry et al., 2005).

PREDIMED study is a multicenter, prospective, randomized, controlled trial whose goals are to assess the efficacy and safety of a Mediterranean diet in primary care of CVD. It was designed in 2002 and it is the first long-term clinical trial that recruits high-risk patients (around 7,000 participants from different regions in Spain) to follow a Mediterranean diet supplemented with virgin olive oil (VOO) (1 liter a week) or nuts (30 g per day of which 15 $\mathrm{g}$ almonds and $15 \mathrm{~g}$ walnuts).

Medi-RIVAGE study is a randomized clinical trial conducted in France on 212 women and men with at least one cardiovascular risk factor. The aims of the study are to evaluate the effect of two types of diet in the prevention of CVD and to investigate biological mechanisms and genetic polymorphisms related to metabolism. On the one hand, they study the traditional Mediterranean diet (35-38\% of total energy from fat: $50 \%$ monounsaturated fatty acids (MUFA), 25\% polyunsaturated fatty acids (PUFA), 25\% SFA) and on the other hand, a low fat diet based on the AHA (30\% of total energy from fat: $33 \%$ MUFA, 33\% PUFA, 33\% SFA).

With regard to studies that analyze final cardiovascular risk phenotypes, two of the most outstanding studies (level I of scientific evidence) are the Lyon Diet Heart Study and the Indio-Mediterranean Diet Heart study. 
The Lyon Diet Heart Study (de Lorgeril et al., 1999), a randomized, controlled trial with freeliving subjects (half of 600 men and women in France), tested the effectiveness of a Mediterranean-type diet (consistent with the new AHA Dietary Guidelines) on composite measures of the coronary recurrence rate after a first myocardial infarction during 46 months. Subjects in the experimental group were instructed by cardiologists and dietitians to adopt a Mediterranean-type diet. They demonstrated the effectiveness of Mediterranean diet in the secondary care of CVD. However, the intervention group with Mediterranean diet received margarine rich in alpha-linolenic fatty acid, fact that distorted the interpretation of results, as margarine is not a component of traditional Mediterranean diet. Something similar happens with the Indo-Mediterranean Diet Heart Study (Singh et al., 2002).

The Indo Mediterranean Diet Heart study is a randomized, single-blind trial in 1000 patients with angina pectoris, myocardial infarction, or surrogate risk factors for CVD. 499 patients were allocated to a diet rich in whole grains, fruits, vegetables, walnuts, and almonds. 501 controls consumed a local diet similar to the step I National Cholesterol Education Program (NCEP) prudent diet. They showed that an Indo-Mediterranean diet, that is rich in alinolenic acid, might be more effective in primary and secondary prevention of CVD than the conventional step I NCEP prudent diet. However, as in the Lyon Diet Heart Study, the intervention group with Mediterranean diet increased the consumption of alpha-linolenic fatty acid from soybean and mustard oil, which are not typical from Mediterranean countries.

\section{Mediterranean diet in determining intermediate cardiovascular disease phenotypes}

There is a great number of studies analysing the effect of the consumption or adherence to Mediterranean diet and intermediate CVD phenotypes. In the following sections we review the studies analysing Mediterranean diet and obesity, lipid metabolism, glucose concentrations, blood pressure and inflammation. Table 1 shows the effect of Mediterranean diet on the aforementioned phenotypes.

\subsection{Mediterranean diet and obesity}

Currently, it is not known which is the best diet is to lose weight (low-carb, high protein, low fat diet, etc.). Consumption of nuts, and high fat diets (rich in MUFA), characteristics of the Mediterranean diet, have been traditionally associated with an increased body weight by its high contain in fats. However, recent scientific evidence does not support these data. Adherence to Mediterranean diet was inversely associated with BMI and obesity in a crosssectional survey carried out in the northeast of Spain (Schröder et al., 2004). Obesity risk decreased in both men and women with increasing adherence to the traditional Mediterranean diet.

Results from epidemiological studies on large populations indicate that subjects who usually consume nuts have lower BMI than those who do not consume (Bes-Rastrollo et al, 2009, Garcia-Lorda et al, 2003; Schroder et al, 2004). In addition, the SUN cohort (Seguimiento Universidad de Navarra) (follow-up University of Navarra) evaluated 11,895 participants and found an inverse association between consumption of nuts and weight gain 
per year (Martinez-Gonzalez \& Bes-Ballostro, 2011). Similarly, a recent study carried out in EPIC-PANACEA project showed that individuals with high adherence to Mediterranean diet, according to the score based on a questionnaire of adherence to Mediterranean diet (1118 points), showed in a weight change of $20.16 \mathrm{~kg}$ (95\% CI :20,2-20, $7 \mathrm{~kg}$ ) 5 years and they were also $10 \%$ less likely to become overweight and obese compared with individuals with lower adherence (0-6 points) (Romaguera et al., 2010). Furthermore, a study that evaluated 497,308 individuals aged between 25-70 years in 10 European countries found that high adherence to the Mediterranean diet is associated with lower abdominal adiposity, using waist circumference as a measure (Romaguera et al., 2009).

With respect to intervention studies, it has been shown that subjects that consume daily tree nuts in their diet are less likely to gain weight (Li et al., 2010). A study evaluating the intake of almonds (42-72 $\mathrm{g}$ daily) in 81 patients over 6 months found that there was no significant weight gain (Fraser et al., 2002). Similarly, García-Londa et al, (2003) found that in the short term, the addition of tree nuts to diet, in amounts up to $50 \mathrm{~g}$ daily, does not increase weight. After one year of intervention in the PREDIMED study, beneficial effects on waist circumference were shown (Martinez-Gonzalez \& Bes-Ballostro, 2011).

Finally, a meta-analysis regarding Mediterranean diet and weight loss analyzing randomize controlled trials has been recently published (Esposito et al., 2011), and it concludes that Mediterranean diet does not cause weight gain, which removes the objection to its relatively high fat content. Mediterranean diet could be a strategy to help people lose weight.

Some of the proposed mechanisms that might explain these facts are that the absorption of nuts may be incomplete, thus some of its fat content may not be absorbed by the body and would be excreted in the feces. Moreover, the consumption of nuts may have a satiating effect, producing a decrease in consumption of other foods and helping to control total energy intake. Although it still has not been proved, there may be an adaptation of the metabolism, so that energy consumption could be more efficient and get the body burn more energy, thus avoiding an accumulation of body fat (Brennan et al., 2010; Garcia-Lorda et al., 2003; Rajaram \& Sabaté, 2006).

\subsection{Mediterranean diet and lipid metabolism}

Mediterranean diet has been largely studied in relation to lipid metabolism because of its beneficial effect on CVD. However, different results have been shown regarding a variety of studies, designs, and sample sizes. Cross-sectional studies with similar characteristics, with a sample size between 1762 and 2032 participants in Greece (ATTICA study), evaluated the adherence to Mediterranean diet and lipid profile. Thus, Tzima et al (2007) reported that subjects who are overweight (BMI 25-29.9) or obese (BMI $\geq 30$ ) in the highest tertile of the Mediterranean diet score had lower total cholesterol (TC) $(-13 \%, \mathrm{P}=0.001)$ after adjusting for age, sex and BMI compared to the first tertile. However, there were no significant differences in triglycerides (TG) and HDL-C. This increase in the adherence to Mediterranean diet was also associated with lower total cholesterol $(p<0.001)$ in a study carried out by Panagiotakos et al (2006). In addition to that, individuals with abdominal obesity and less physically active had lower adherence to Mediterranean diet $(p=0.008)$ with lower HDL-C ( $\mathrm{p}<0.05)$ (Pitsavos et al., 2007). 
Moreover, seven studies of 29 clinical trials with 3,822 subjects (2,202 assigned to Mediterranean diet and 1,903 assigned to a control diet) reported beneficial effects of adherence to Mediterranean diet on HDL-C (Papadaki \& Scott, 2008; Esposito et al., 2004; Estruch et al., 2006; Esposito et al., 2003; Esposito et al., 2009; Athryros et al., 2011). A recent meta-analysis (Kastorini et al., 2011) showed that, overall, adherence to Mediterranean diet was associated with higher HDL-C levels as compared with a control diet.

Benefits in TC have also been shown in some randomized controlled trials (Estruch et al., 2006; Vincent-Baudry et al., 2005; Ambring et al., 2004). In this sense, Estruch et al., (2006) carried out a study of 3 months with individuals who had diabetes mellitus or one or more cardiovascular risk factors, which were assigned to three intervention groups ( $\mathrm{n}=257-8$ / group) (2 Mediterranean diet (one supplemented with VOO and another one with $15 \mathrm{~g}$ of almonds+15g walnuts/day) and one control diet low in fats). Regarding the lipid profile, both Mediterranean diets showed significant increase in HDL-C levels $(p=<0.001$ and $p=$ 0.006 , respectively) and a significant reduction ( $\mathrm{p}<0.001$ and $\mathrm{p}=0.002$, respectively) in the atherogenic index (TC/HDL-C) in contrast to the control group. However, only Mediterranean diet supplemented with nuts showed a significantly reduction in TC $(\mathrm{p}=$ $0.040)$ and TG $(p=0.022)$, compared to control. Neither of the Mediterranean diets significantly reduced LDL-C compared to the control diet (low fat diet).

Concerning TG, three observational studies reported a beneficial effect of Mediterranean diet (Chrysohoou et al., 2004; Tzima et al., 2007; Barzi et al., 2003) as compared with low adherence to Mediterrenean diet. Five interventional studies showed beneficial effects of Mediterranean diet on TG concentrations (Shai et al., 2008; Esposito et al., 2004; Estruch et al., 2006; Esposito et al., 2009; Elhayany et al., 2011), whereas other studies did not find significant differences (de Lorgeril et al., 1994; Castro et al., 2000; Michalsen et al., 2006).

Moreover, results from a crossover study during 4 weeks for each intervention (22 healthy people $(12 \mathrm{H} / 10 \mathrm{M})$ ) found an improvement in lipid profile to compare a Mediterranean diet (rich in omega 3) with a Swedish standard diet (Ambring et al., 2004). The results showed a significant decrease in TC, LDL-C, TG $(17 \%, 22 \%$, and 17\%) in the group with Mediterranean diet. On the other hand, one non-randomize control trial carried out in Italy (47 obese women) during 4-month with an hypoenergetic Mediterranean diet together with a program of physical exercise showed a significant decrease in total cholesterol and TG concentrations. Levels of LDL-C decreased ( $\mathrm{p}<0.001$ ) after 4 months of intervention, whereas HDL-C increased (Andreoli et al., 2008). However, another study carried out in 71 healthy Canadian found a significant decrease in TC at 6 weeks of intervention $(p<0.05)$, whereas no significant changes were observed after 12 weeks. Levels of HDL-C, LDL-C and TG were not affected after 6 or 12 weeks of intervention (Goulet et al., 2003). Different characteristics of the recruitment of individuals can influence the final results of the studies.

The relationship between nut consumption and reduced risk of CVD has been established in numerous epidemiological studies. Thus, Ros et al (2004), in a crossover study carried out in hypercholesterolemia subjects in Spain, determined whether a diet containing nuts $(18 \%$ of energy) could improve markers related to endothelial function against another typical Mediterranean diet with similar energy intake, fat, protein, carbohydrates, but not MUFA intake, after 4 weeks. Estruch et al (2006) also found a significant decrease in TC ( $p=0.017)$ and LDL-C $(p=0.010)$. However, no differences were found in TG concentrations and HDL- 
C. Pooled analysis in 25 clinical trials to evaluate nut consumption in blood lipids showed that the most important finding is that the cholesterol-lowering effects of nut consumption are dose related and are more pronounced in subjects with higher baseline LDL-C or lower BMI. Nut consumption also lowered TG levels in subjects with hypertriglyceridemia (Sabate et al., 2010).

\subsection{Mediterranean diet and glucose concentrations}

The increasing incidence of type 2 diabetes throughout the world is also linked to westernized dietary patterns. Lifestyle changes are effective measures to prevent diabetes. The Mediterranean diet has also shown beneficial effects on diabetes risk and glucose concentrations.

Two observational studies reported a beneficial effect of close adherence to Mediterranean diet as compared with a control diet in lowering fasting glucose (FG) levels (Tzima et al., 2007; Panagiotakos et al., 2007).

Furthermore, Estruch et al., 2006 found that participants in the intervention group with Mediterranean diet supplemented with VOO or nuts, showed a significant reduction in FG compared with the control group $(-0.39 \mathrm{mmol} / \mathrm{L}$ and $-0.30 \mathrm{mmol} / \mathrm{L}$, respectively).

In this sense, in another randomized controlled trial (Vincent-Baudry et al., 2005) with Mediterranean diet or low-fat diet, after 3 months of intervention, both diets significantly reduced blood glucose, insulinemia, insulin resistance and HOMA-IR index. Insulin levels remained significant after adjusting for BMI. However, there was no interaction between time and type of diet for any of the variables. Negative results were shown in a study that compared the intervention with Mediterranean diet rich in omega 3 versus the standard Swedish diet (Ambring et al., 2004). Recently, results from PREDIMED study also reported that, after a median follow-up of 4 years, diabetes incidence was lower in the groups with Mediterranean diet as compared with control group (10,1\% in Mediterranean diet with VOO, $11 \%$ in Mediterranean diet with nuts, $17,9 \%$ in control group) (Salas-Salvado et al., 2011).

In conclusion, overall adherence to Mediterranean diet is associated with lower FG levels as compared with the control diet (Kastorini et al., 2011). Among the mechanisms associated with that decrease in glucose levels are the properties of the components of Mediterranean diet. Fiber delays gastric emptying, antioxidants increase oxidative capacity and moderate alcohol could have a role in adiponectin. As a consequence, it ends in the prevention of insulin resistance and, finally, in prevention of type 2 diabetes (Schröder, 2007).

\subsection{Mediterranean diet and blood pressure}

Nutritional factors and dietary patterns have been associated with hypertension. Hypertensive individuals can remarkably reduce their blood pressure through nutritional changes. Mediterranean diet has also shown beneficial effects in the prevention and control of blood pressure.

Cross-sectional studies associate the consumption of Mediterranean diet with lower systolic blood pressure (SBP). Higher adherence to Mediterranean diet was associated with lower SBP ( $<<0.001$ ) (Tzima et al., 2007; Panagiotakos et al., 2006) as well as with $70 \%$ of decrease of prevalence of hypertension (Alvarez-León et al., 2006). In contrast, lower adherence was 
associated with increased blood pressure (BP) (Pitsavos et al., 2007). However, one study showed higher SBP in the group more closely following the Mediterranean diet in the SUN cohort in young individuals after a median follow-up of 4.2 years (Nunez-Cordoba et al., 2009). Most of the effects of the Mediterranean diet on blood pressure have been attributed to the consumption of olive oil, fruits, nuts and vegetables. Psaltopoulou et al (2004) in the Greek-EPIC cohort studied whether Mediterranean diet together or olive oil in particular reduced blood pressure in 20,343 people without a diagnosis of hypertension. In this study, the Mediterranean diet score was inversely and significantly associated with both, SBP and diastolic blood pressure (DBP), as well as the intake of olive oil, fruits and vegetables. However, Giuseppe et al (2008) found a significant and positive association of BP with the rate of adaptation to the Mediterranean diet. However, we have to consider that the study was carried out in older women (> 60 years). In the Italian EPIC Florence cohort, which include more than 10,000 non-hypertensive women aged 35-64 years, consumption of olive oil was inversely associated with DBP (Masala et al., 2008). However, with regard to DBP and Mediterranean diet as a whole, observational studies did not found significant associations (Kastorini et al., 2011).

Regarding randomized clinical trials (level I scientific evidence) in a meta-analysis, it was found that the overall adherence to Mediterranean diet was associated with lower SBP and DBP as compared with control diet (Kastorini et al., 2011). In the PREDIMED study, results showed a significant decrease in both SBP and DBP in the two groups with Mediterranean diet (one supplemented with VOO and another with nuts) as compared with control group (Estruch et al., 2006). Finally, in a non-randomized clinical trial whose aim was to evaluate the effect of a moderately hypoenergetic Mediterranean diet with an exercise program in women with overweight-obesity, DBP decreased significantly $(p<0.001)$ after two months of intervention, while the SBP was not changed significantly after four months of intervention (Andreoli et al., 2008).

In conclusion, as we mention before, the beneficial effects of the Mediterranean diet on blood pressure have been attributed to a synergy of its components, especially to fruits, vegetables, nuts and olive oil. These components are low in sodium and rich in minerals (magnesium, potassium and calcium), antioxidant, fiber, PUFA and MUFA, all of them with potentially protective properties against hypertension.

\subsection{Mediterranean diet and inflammation}

Obesity and other related diseases associated with CVD are caused or related to inflammation. Three of five cross-sectional studies, showed a significant decrease in inflammation markers with higher adherence to Mediterranean diet (Sotos-Prieto et al., 2010). Thus, Panagiotakos et al (2006) found significant negative association between adherence to Mediterranean diet and protein $C$ reactive $(C R P)(p<0.001)$. Also, the highest score in the AHEI index (Alternate Healthy Eating Index) and AMED (alternate mediterranean diet index) was associated with lower inflammation biomarkers concentrations (IL-6 and CRP) (24\% and 16\% respectively). This study was carried out in 690 nurses, in the Nurses' Health Study (Fung et al., 2005). Moreover, subjects in the highest tertile of adherence to Mediterranean diet had $20 \%$ lower CRP levels $(p=0.015)$ and $17 \%$ IL$6(p=0.025)$ (Chrysohoou et al., 2004), while the lower adherence to Mediterranean diet was associated with higher levels of CRP (> $3.0 \mathrm{mg} / \mathrm{ml}$ ) (Pitsavos et al., 2007). 
Salas-Salvado et al (2008), in a study that included subjects with high cardiovascular risk $(339 \mathrm{H} / 433 \mathrm{M}, 55-80$ years), found an association between consumption of certain foods that characterized the Mediterranean pattern (fruits, cereals, VOO and nuts) with lower concentrations of inflammatory markers, especially those related to endothelial function (ICAM-1 and VCAM-1). However, participants with higher adherence to a Mediterranean diet showed no significant decrease in the inflammatory biomarkers' concentrations (CRP, IL-6, ICAM-1 and VCAM-1), although there was a statistical trend in the case of ICAM-1 and VCAM-1 ( $\mathrm{p}<0.1)$.

In two randomized controlled trials, CRP levels decreased only in the group with Mediterranean diet supplemented with VOO (-0.54 mg / L) compared with the control group (low-fat). The IL-6 decreased in both groups with Mediterranean diet (VOO and nuts), whereas it increased in the group with low-fat diet. Similarly, Esposito et al (Esposito et al., 2004), in a study conducted in Italy with 180 people with metabolic syndrome $(99 \mathrm{H}$, $81 \mathrm{M})$, observed a significant decrease in CRP $(\mathrm{p}=0.01)$ and IL-6 $(\mathrm{p}=0.04)$ in the intervention group (instructed to follow a Mediterranean diet) compared with the control group (prudent diet with fat percentage $<30 \%$ ) after two years. By contrast, Michalsen et al (2006) found no changes in CRP levels, although there were some limitations in the study.

In a non-randomized clinical trial, plasma levels of CRP decreased significantly $(6 \%, \mathrm{P}$ $<0.02)$ after two hours of Mediterranean diet rich in MUFA intake (Blum et al., 2006).

In conclusion, Mediterranean diet is characterized by a high consumption of fruit and vegetables. This adds other mechanistic benefits provided by their polyphenolic content to its high antioxidant content that could be linked with the prevention of inflammation. Other components of the Mediterranean diet such as VOO and red wine gather antioxidants and anti-inflammatory actions that may contribute to the healthy effects of this diet on inflammation.

\begin{tabular}{|l|l|l|l|}
\hline & Decrease & Increase & No significant \\
\hline BMI (kg/m²) & $\begin{array}{l}\text { Scröder et al., 2004 } \\
\text { Romaguera et al., 201 } \\
\text { Bes-Ballostro et al., 2009; Garcia- } \\
\text { Londa et al., 2003 } \\
\text { Martinez-Gonzalez \& Bes- } \\
\text { Ballostro, 2011 }\end{array}$ & & \\
\hline Weight gain & $\begin{array}{l}\text { Fraser et al., 2002 } \\
\text { Martinez-Gonzalez \& Bes- } \\
\text { Ballostro, 2011 }\end{array}$ & & \\
\hline $\begin{array}{l}\text { Waist } \\
\text { circumference }\end{array}$ & $\begin{array}{l}\text { Romaguera et al., 2002 } \\
\text { Martinez-Gonzalez \& Bes- } \\
\text { Ballostro, 2011 }\end{array}$ & & \\
\hline TC & $\begin{array}{l}\text { Estruch et al.,2006 } \\
\text { Vicent-Baudry et al., 2005 } \\
\text { Ambring et al., 2004 }\end{array}$ & & \\
\hline LDL-C & $\begin{array}{l}\text { Vicent-Baudry et al., 2005 } \\
\text { Ambring et al., 2004 } \\
\text { Ros et al., 2004 } \\
\text { Andreoli et al., 2008 }\end{array}$ & & \\
& & & $\begin{array}{l}\text { Michalsen et al., } \\
\text { 2006 } \\
\text { Goulet et al., } \\
\text { 2003 } \\
\text { Estruch et al., } \\
\text { 2006 }\end{array}$ \\
\hline
\end{tabular}




\begin{tabular}{|c|c|c|c|}
\hline & Decrease & Increase & No significant \\
\hline HDL-C & Pitsavos et al., 2007 & $\begin{array}{l}\text { Estruch et al, } 2006 \\
\text { Andreoli et al.,2008 } \\
\text { Papadaki \& Scott, } 2008 \\
\text { Esposito et al., 2004; } \\
\text { Esposito et al., 2003; Esposito et } \\
\text { al., 2009; Athryros et al., } 2011 \\
\text { Ambring et al., } 2004 \\
\end{array}$ & $\begin{array}{l}\text { Michalsen et al., } \\
2006 \\
\text { Goulet et al., } \\
2003\end{array}$ \\
\hline TG & $\begin{array}{l}\text { Estruch et al.,2006 } \\
\text { Vicent-Baudry et al., } 2005 \\
\text { Ambring et al., } 2004 \\
\text { Ros et al., } 2004 \\
\text { Chrysohoou et al., 2004; } \\
\text { Tzima et al., 2007; } \\
\text { Barzi et al., 2003 } \\
\text { Shai et al., 2008 } \\
\text { Esposito et al., } 2004 \\
\text { Esposito et al., } 2009 \\
\text { Elhayany et al., } 2011 \\
\text { Sabate et al., 2010 }\end{array}$ & & $\begin{array}{l}\text { Michalsen et al., } \\
2006 \\
\text { de Lorgeril et } \\
\text { al., } 1994 \\
\text { Castro et al., } \\
2000 \\
\text { Goulet et al., } \\
2003\end{array}$ \\
\hline Glucose & $\begin{array}{l}\text { Estruch et al., } 2006 \\
\text { Vicent-Baudry et al., } 2005 \\
\text { Andreoli et al.,2008 } \\
\text { Panagiotakos et al., } 2007 \\
\text { Tzima et al., } 2007 \\
\text { Salas-Salvado et al., } 2011 \\
\end{array}$ & & $\begin{array}{l}\text { Ambring et al., } \\
2004\end{array}$ \\
\hline SBP & \begin{tabular}{|l} 
Estruch et al., 2006 \\
Tzima et al., 2007 \\
Psaltopoulou et al., 2004 \\
Panagiotakos et al., 2006
\end{tabular} & $\begin{array}{l}\text { Giussepe et al., } 2008 \\
\text { Nunez-Cordoba et al., } 2009\end{array}$ & $\begin{array}{l}\text { Andreoli et al., } \\
2008\end{array}$ \\
\hline BP & $\begin{array}{l}\text { Estruch et al., } 2006 \\
\text { Andreoli et al., } 2008 \\
\text { Alvarez-Leon et al., } 2006 \\
\text { Psaltopoulou et al., } 2004 \\
\text { Pitsavos et al., } 2007 \\
\text { Masala et al., 2008 } \\
\end{array}$ & & \\
\hline CRP & $\begin{array}{l}\text { Estruch et al., } 2006 \\
\text { Esposito et al., } 2004 \\
\text { Blum et al., 2006 } \\
\text { Fung et al., } 2005 \\
\text { Chrysohoou et al., } 2004 \\
\text { Panagiotakos et al., } 2006\end{array}$ & Pitsavos et al., 2007 & $\begin{array}{l}\text { Michalsen et al., } \\
2006 \\
\text { Salas-Salvado et } \\
\text { al., } 2008\end{array}$ \\
\hline IL-6 & $\begin{array}{l}\text { Estruch et al., } 2006 \\
\text { Esposito et al., } 2004\end{array}$ & & $\begin{array}{l}\text { Salas-Salvado et } \\
\text { al., } 2008\end{array}$ \\
\hline
\end{tabular}

BMI: Body mass index; TC: Total Cholesterol; LDL-C: Low density lipoprotein cholesterol HDL: High density lipoprotein cholesterol; TG: Triglycerides; SBP: Systolic blood pressure; BP: Blood pressure; CRP: Protein C reactive; IL-6: Interleukin 6

Table 1. Studies that analyze Mediterranean diet and variation (decrease, increase, no significant) in intermediate cardiovascular disease phenotypes. 


\section{Nutritional genomics}

Current changes in lifestyle, in part promoted by the nutritional transition, have contributed to the development of CVD, cancer and other non-comunicable diseases.

Since the Human Genome Project finished in April 2003, we have the information about the complete genome. However, we still unknown the role of the majority of genes involved in the development of CVD. For that reason, currently, considering diet as one of the most important environmental factor, the molecular nutrition begins with the approach to better understand the mechanism involved in the gene-diet interaction and to personalize the diet with the aim to prevent common diseases, among them, CVD. Since Human Genome Project finished, the classic candidate gene approach and the new genome-wide association studies have identified genetic variants that predispose people to CVD.

In this sense, it was shown that human genome is sensitive to nutritional environment in two ways: nutrients may regulate genes and genes also influence the effect of diet (Loktionov, 2003). Nutritional health is dependent on the interaction between the environmental aspects of dietary components and the genetically controlled aspects (Figure 1). The concept of gene-diet interaction describes the modulation of the effect of a dietary component on a specific phenotype (plasma lipid concentrations, obesity, etc.) by a genetic polymorphism (Ordovas \& Corella, 2004). A better understanding of these interactions has the potential to support disease prevention and will lead to different requirements between individuals via modification of dietary recommendations. This research has led to the development of concepts that study the effect of genetic variation on the interaction between diet and specific phenotypes known as nutrigenetics.

The goal of nutrigenetics is to generate personalized recommendations regarding the genetic susceptibility of each individual. It is also known as personalized nutrition.

On the other hand, the study of the characterization of gene products and the physiological function and interactions of these products is known as nutrigenomics (Figure 1). The unifying term "nutritional genomics" refers to nutrigenomics and nutrigenetics (Ordovas \& Corella, 2004). The term Nutrigenetics was named for the first time by Brennan in 1975 in his book "Nutrigenenetics: New concepts for Relieving Hypoglycemia", while nutrigenomics was used in 1999 by DellaPenna when he studied the plant genomics field. The new technology research together with the knowledge of the human genome sequence have led in the study of the new "omics" to better understand the molecular basis of the disease development. They are the disciplines known as:

- Transcriptomic: to quantify the level of gene expression by using techniques to analyse thousands of mRNA molecules at the same time by using a technique based on microarrays.

- Proteomic: large-scale study of proteins (particularly their structure and function) is possible to identify proteins that can diagnose disease or predict the evolution of it.

- Metabolomics: to study techniques dedicated to complete a system composed of a series of molecules that are metabolic intermediates, metabolites, hormones and other signal molecules, and secondary metabolites, which can be found in a biological system.

- Systems Biology: integration of proteomic data, genetic, metabolomics.

- Bioinformatics: to interpret the data to provide biological mechanisms to explain the experimental observations. 
Following these new concepts, other related terms have emerged: nutritranscriptomic (the study of messenger RNA expression at the cellular level under some nutritional conditions), nutriproteomic (large-scale analysis of the structure and function of the protein, as well as protein-protein interactions in a cell to identify molecular targets of dietary components) or nutrimetabolomic (measuring all metabolites in response to stimuli nutritional body) (Panagiotou \& Nielsen, 2009).

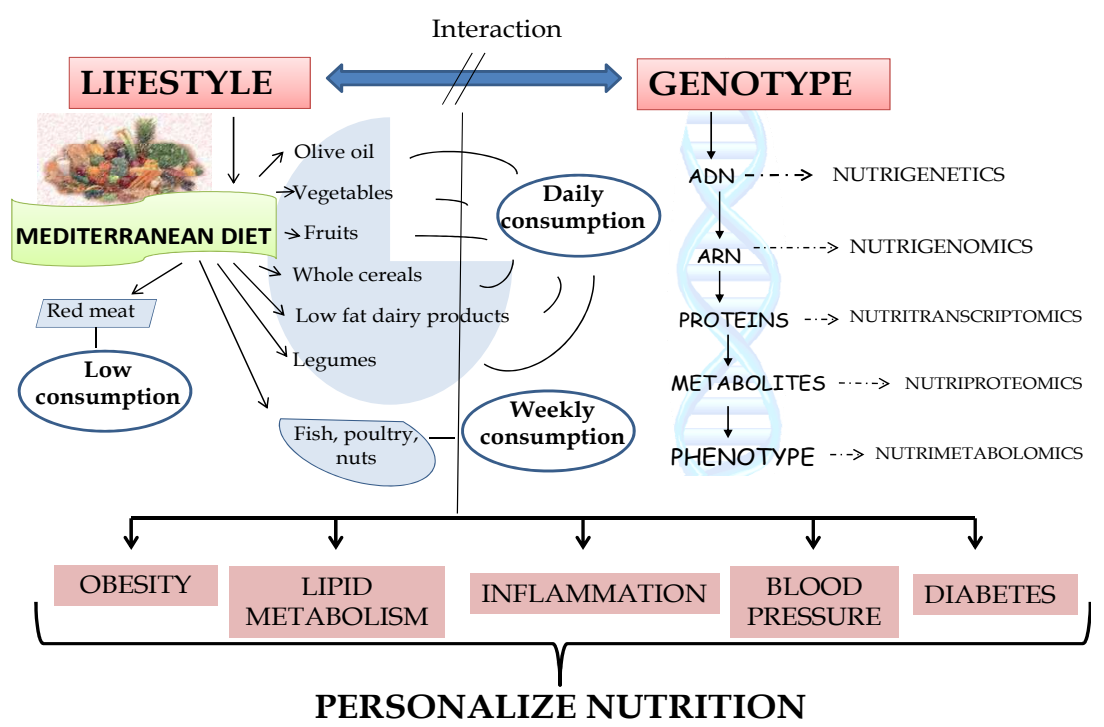

Fig. 1. Personalized Nutrition. As part of health determinants, lifestyle interacts with genetic susceptibility to modulate obesity risk, lipid metabolism, inflammation, blood pressure and diabetes. Among lifestyle factors, diet, and especifically, Mediterrranean diet, has an important role in gen-diet interactions. On the other hand, with the new technology research together with the knowledge of human genome sequence have led in the study of the nutrigenetics and nutrigenomics (nutritional genomics) to better understand the molecular basis of the disease development, they are the disciplines knows as: transcriptomic, proteomic, metabolomic that allow us to know phenotypes characteristics. These interactions between Mediterranean diet and genetic susceptibility will contribute to create personalized diets.

\section{Gene-Mediterranean diet interaction in intermediate cardiovascular diseases phenotypes}

In the following sections we are going to review some studies analyzing nutrigenetics and nutrigenomics effects on CVD.

\subsection{Nutrigenetics in the prevention of cardiovascular diseases}

In the last decades the eating pattern has changed considerably towards less healthy habits with excessive intake of calories and SFA. Considering this as a risk factor of CVD these 
changes are contributing to the increase of CVD. As a result, researchers are wondering which could be the best diet to prevent CVD and related phenotypes. Different opinions have emerged about the virtues of low-carbohydrate diets, low fat diets, high-protein diets or Mediterranean dietary pattern in the control of body weight and factors related to CVD (Shai et al., 2008, Larsen et al., 2010, Sacks et al., 2009).

Given the great diversity that exists with regard to dietary recommendations and their effects, several authors insist on the fact that there is no perfect diet. Diet will be different depending on individual characteristics. The response to the same diet has not the same effectiveness on different two people. While some people appear to have no response to dietary intervention (hiporesponders), others have a high response (hiperresponders) (Katan MB et al., 1986). It has been suggested that this inter-individual variability to dietary modification is determined by genetic factors, especially for phenotypes related to lipid metabolism (Loktionov, 2003).

Most of the studies carried out to determine whether genetic factors could explain these differences are based on the study of single nucleotide polymorphisms (SNPs) as well as dietary factors, particularly those that characterize Mediterranean Diet. The table 2 shows some studies conducted to assess genetic modulations according to different types of diets or macronutrients. In the following paragraphs we describe the results from intervention studies and observational studies that analyze gene-diet interactions on CVD.

\section{Results from intervention studies}

Intervention studies in which subjects receive a controlled dietary intake provide the most valuable information for the study of gene-nutrient-phenotype association. However, intervention studies have some limitations, such as the low number of participants. The sample size is important in nutrigenetic studies because otherwise, there is a lack of statistical power to assess the main associations. Something similar happens with the study of some genetic variants. Prevalence of certain polymorphisms is small and requires a large sample size to study these associations. Another limitation is the short duration of these interventions. A review conducted by Masson et al, (2003) concluded that there is evidence to suggest that variations in the $A P O A 1, A P O A 4, A P O B$ and $A P O E$ genes contribute to the heterogeneity of the lipid response to dietary interventions, and that these genes are directly or indirectly regulated by PPAR or other nuclear receptors. New examples that confirm the importance of gene-diet interaction in the field of nutrigenetics are the study of the perilipin gene (PLIN) (Corella D et al., 2005, Smith CE et al., 2010) and SR-BI (Perez-Martinez P et al., 2005).

Recently, some studies investigating the genetic modulation of the Mediterranean diet in PREDIMED study have been published. Thus, a study examining a polymorphism in the FTO gene (associated with obesity) shows that the A allele of the polymorphism rs 9939609 in the FTO gene was not associated with baseline body weight, but after 3 years of nutritional intervention with Mediterranean diet carriers of $\mathrm{A}$ allele had a lower body weight gain than subjects with the ancestral allele (Razquin C et al., $2010 \mathrm{~A}$ ).

Another example carried out in the PREDIMED study showed that CC subjects for the polymorphism-174G / C in the $I L-6$ gene had a lower weight gain after three years only in those subjects who followed a Mediterranean diet supplemented with nuts and olive oil (Razquin et al., 2010 B) 


\section{Results from observational studies}

Observational studies have the advantage of incorporating a large number of participants and the ability to estimate dietary habits. They also have the advantage that the distribution of genetic variants in the population is independent of eating behaviors by the principle of Mendelian randomization. Although nowadays the number of studies examining gene-diet interactions is increasing, few studies have investigated the interaction between SNPs in candidate genes and cardiovascular risk factors analyzing the consumption of Mediterranean diet or intake of MUFA, PUFA or SFA.

One of the most studied genes has been the Pro12Ala polymorphism in the PPARG gene and its interaction with MUFA intake. Obese subjects with the Ala12 allele have higher HOMA index when they eat low amounts of MUFA. Another example analyzing MUFA intake and body weight depending on variation in APOA5 gene is one carried out in the Framingham study. They found a significant interaction between the promoter polymorphism $-1131 \mathrm{~T}>\mathrm{C}$ in the APOA5 gene and fat intake, particularly MUFA, regulating body weight (Corella D et al., 2007). The study of C677T polymorphism in the gene for methylenetetrahydrofolate reductase (MTHFR) is another example of modulation of LDL oxidation by the Mediterranean diet (Pitsavos et al., 2006). Recently, we published a significant gene-diet interaction in a variant of the promoter of APOA2 gene. This study included 3462 volunteers from three different populations and it studied the interaction between the polymorphism-265T $>\mathrm{C}$ in the APOA2 gene, food intake, and BMI. Carriers of the variant allele which had higher intake of SFA had a higher prevalence of obesity while this was not showed if the source of fat was MUFA or PUFA. These results were replicated for the first time in three independent populations (Corella et al., 2009). Subsequently, the authors replicated this interaction in Mediterranean and Chinese populations (Corella et al., 2011) confirming the importance of genetic modulation by dietary factors, and also the need to replicate gene-diet interactions to increase the scientific evidence and finally to contribute to personalize diet based on genetic susceptibility.

\begin{tabular}{|c|c|c|c|c|}
\hline Author & \multicolumn{2}{|c|}{ Phenotype } & Gene & Gen-diet interaction \\
\hline $\begin{array}{l}\text { Lopez- } \\
\text { Miranda } \\
\text { et al., } \\
1994 \\
\end{array}$ & \multirow{6}{*}{ 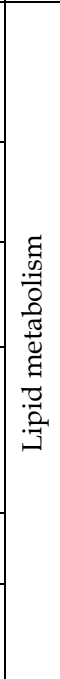 } & LDL-C & -75G>A APOA1 & $\begin{array}{l}\text { They studied the influence of the LDL-C } \\
\text { postprandial response to MUFA intake. After } \\
\text { high MUFA intake carriers of A allele had } \\
\text { higher LDL-C but not the GG. }\end{array}$ \\
\hline \begin{tabular}{|l|} 
Jansen et \\
al., 1997
\end{tabular} & & \begin{tabular}{|l|} 
LDL-C \\
\end{tabular} & Thr347Ser APOA4 & $\begin{array}{l}\text { 347Ser carriers had lower LDL-C postprandial } \\
\text { response when they switched from a diet rich } \\
\text { in SFA to a diet based on NCEP. }\end{array}$ \\
\hline \begin{tabular}{|l|} 
Campos \\
et al., \\
2001
\end{tabular} & & \begin{tabular}{|l|} 
VLDL, \\
HDL-C
\end{tabular} & APOE & $\begin{array}{l}\text { Higher VLDL and lower HDL-C in E2 with a } \\
\text { high SFA intake. }\end{array}$ \\
\hline $\begin{array}{l}\text { Corella } \\
\text { et al., } \\
2001\end{array}$ & & LDL-C & APOE & $\begin{array}{l}\text { E2 carriers had lower LDL-C in those with } \\
\text { moderate alcohol consumption than in non- } \\
\text { consumers. However, carriers of E4 allele that } \\
\text { had a moderate alcohol consumption had } \\
\text { higher LDL-C. }\end{array}$ \\
\hline $\begin{array}{l}\text { Brown et } \\
\text { al., } 2003\end{array}$ & & $\begin{array}{l}\text { TC and } \\
\text { LDL-C }\end{array}$ & T455С y T625 APOC3 & $\begin{array}{l}\text { In -45T and -625T homozygous subjects, SFA } \\
\text { intake was associated with higher LDL-C. }\end{array}$ \\
\hline $\begin{array}{l}\text { Tai et al., } \\
2005\end{array}$ & & \begin{tabular}{|l|} 
TG and \\
APOCIII
\end{tabular} & L162V PPARA & $\begin{array}{l}\text { Carriers of } 162 \mathrm{~V} \text { allele had higher TG } \\
\text { concentrations and APOC3 levels only in that } \\
\text { subjects with a low PUFA consumption. }\end{array}$ \\
\hline
\end{tabular}




\begin{tabular}{|c|c|c|c|c|}
\hline Author & \multicolumn{2}{|c|}{ Phenotype } & \multirow{2}{*}{\begin{tabular}{|l} 
Gene \\
Leu72Met Grelina
\end{tabular}} & \multirow{2}{*}{$\begin{array}{l}\text { Gen-diet interaction } \\
\begin{array}{l}\text { Interaction with fat intake modulating TG } \\
\text { concentrations. }\end{array}\end{array}$} \\
\hline $\begin{array}{l}\text { Robitaill } \\
\text { e et al., } \\
2007\end{array}$ & & Lipids & & \\
\hline $\begin{array}{l}\text { Ordovas, } \\
2002\end{array}$ & & HDL-C & $-514 \mathrm{C}>\mathrm{T}$ LIPC & $\begin{array}{l}\text { T alelle was associated with higher HDL-C in } \\
\text { subjects that had an intake of fat }<30 \% \text { of total } \\
\text { energy. }\end{array}$ \\
\hline $\begin{array}{l}\text { Luan et } \\
\text { al., } 2001\end{array}$ & \multirow{9}{*}{ 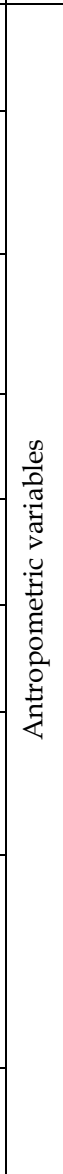 } & BMI & Pro12Ala PPARG & $\begin{array}{l}\text { AlaPPARG carriers had higher BMI than } \\
\text { ProPPRG, but when the ratio PUFA:SFA was } \\
\text { high, opposite results were shown. }\end{array}$ \\
\hline $\begin{array}{l}\text { Memisog } \\
\text { lu et al., } \\
2003\end{array}$ & & BMI & Pro12Ala PPARG & $\begin{array}{l}\text { Among ProPro subjects, those with higher fat } \\
\text { intake of had higher BMI compared to those } \\
\text { with lower intake. No association was shown } \\
\text { for 12Ala. }\end{array}$ \\
\hline \begin{tabular}{|l|} 
Robitaill \\
e et al., \\
2007
\end{tabular} & & WC & Pro12Ala PPARA & $\begin{array}{l}\text { Interaction Pro12Ala with the intake of fat } \\
\text { modulating waist circunference. }\end{array}$ \\
\hline \begin{tabular}{|l|} 
Corella \\
et al., \\
2009 \\
\end{tabular} & & $\begin{array}{l}\text { BMI and } \\
\text { Obesity }\end{array}$ & $\begin{array}{l}-265 \mathrm{~T}>\mathrm{C} \\
\text { APOA2 }\end{array}$ & $\begin{array}{l}\text { C carriers that had high SFA intake had higher } \\
\text { prevalence of obesity. }\end{array}$ \\
\hline \begin{tabular}{|l|} 
Corella \\
et al., \\
2011 \\
\end{tabular} & & \begin{tabular}{|l}
$\begin{array}{l}\text { BMI and } \\
\text { obesity }\end{array}$ \\
\end{tabular} & $\begin{array}{l}-265 \mathrm{~T}>\mathrm{C} \\
\text { APOA2 }\end{array}$ & $\begin{array}{l}\text { Interaction of }-265 C C \text { with SFA intake } \\
\text { modulating risk of obesity. }\end{array}$ \\
\hline \begin{tabular}{|l|} 
Corella \\
et al., \\
2010 \\
\end{tabular} & & \begin{tabular}{|l|}
$\begin{array}{l}\text { BMI and } \\
\text { obesity }\end{array}$ \\
\end{tabular} & rs9939609 FTO & $\begin{array}{l}\text { Interacction of rs9939609 with educational } \\
\text { level. A carriers had higher risk of obesity and } \\
\text { BMI only in those without uneversity studies. }\end{array}$ \\
\hline $\begin{array}{l}\text { Razquin } \\
\text { et al., } \\
2010 \text { (A) }\end{array}$ & & Weight & rs9939609 FTO & $\begin{array}{l}\text { A allele was associated with higher weight at } \\
\text { the beginnung of the study. After three years } \\
\text { of intervention with Mediterranean diet, A } \\
\text { carriers had a lower weight gain. }\end{array}$ \\
\hline $\begin{array}{l}\text { Razquin } \\
\text { et al., } \\
2010(C)\end{array}$ & & Weight & $\begin{array}{l}+45 \mathrm{~T} / \mathrm{G},+276 \mathrm{G} / \mathrm{T} \\
\text { Adiponectin }\end{array}$ & $\begin{array}{l}\text { Genotype GG }(+45 \mathrm{~T} / \mathrm{G}) \text { was associated with } \\
\text { higher weight gained during three years of } \\
\text { intervention. TT }(+276 \mathrm{G} / \mathrm{T}) \text { was associated } \\
\text { with higher weight gain in men. } \\
\text { Mediterranean diet suplemented with VOO } \\
\text { and nuts reverted this effects. }\end{array}$ \\
\hline $\begin{array}{l}\text { Razquin } \\
\text { et al., } \\
2010 \text { (B) }\end{array}$ & & Weight & $\begin{array}{l}-174 G / C \\
\text { IL-6 }\end{array}$ & $\begin{array}{l}\text { CC subjects that followed Mediterranean diet } \\
\text { suplemented with VOO had lower weight gain } \\
\text { after three years of intervention. }\end{array}$ \\
\hline
\end{tabular}

LDL-C: Low density lipoprotein cholesterol; VLDL: Very low density lipoprotein cholesterol HDL: High density lipoprotein cholesterol; TC: Total cholesterol; BMI: Body mass index WC: Waist circumference

Table 2. Nutrigenetics studies analysing gene-diet interactions.

\subsection{Nutrigenomics in the prevention of cardiovascular diseases}

As we explained in the previous section, there is increasing evidence that Mediterranean diet, whose emblematic component is virgin olive oil (VOO), has a beneficial effect on diseases associated with CVD and other diseases (neurodegenerative diseases, cancer). 
VOO is a functional food containing high levels of MUFA and a number of minor components (bioactive components). These components are known as phenolic compounds. These phenolic compounds have a key role in plasma lipid concentrations and oxidative damage (that is related to CVD). It is believed that the benefits from the consumption of $\mathrm{VOO}$ are due to the interaction of its nutrients and minor components with genes. Several studies have shown changes in gene expression mediated by the consumption of VOO. In table 3 some studies analyzing changes in gene expression of some genes related to CVD by Mediterranean diet or its components are shown.

\begin{tabular}{|c|c|c|c|c|}
\hline Autor & N / duración & Intervención & $\begin{array}{l}\text { Cambios de } \\
\text { expresión }\end{array}$ & Ruta implicada \\
\hline $\begin{array}{l}\text { Konstantinidou } \\
\text { et al., } 2010\end{array}$ & $\begin{array}{l}\mathrm{N}=90 \text { (20-50 years) } \\
3 \text { months }\end{array}$ & $\begin{array}{l}\text { 1. } \mathrm{MD}+\mathrm{VOO} \\
\text { 2. } \mathrm{MD}+\mathrm{VOO} \\
\text { 3. Control }\end{array}$ & \begin{tabular}{|l|} 
INF-y \\
ARHGAP15 \\
IL7R \\
ADRB2 \\
POLK
\end{tabular} & $\begin{array}{l}\text { Inflammation } \\
\text { Oxidative stress }\end{array}$ \\
\hline $\begin{array}{l}\text { Konstantinidou } \\
\text { et al., } 2009\end{array}$ & $\begin{array}{l}\mathrm{N}=6 \\
\text { Postprandial study } \\
(0-6 \mathrm{~h})\end{array}$ & $\begin{array}{l}50 \mathrm{ml} \text { VOO } \\
\text { (26082 genes) }\end{array}$ & \begin{tabular}{|l} 
USP48 \\
OGT \\
AKAP13 \\
IL10 \\
DCLRE1C \\
POLK
\end{tabular} & $\begin{array}{l}\text { Cellular process } \\
\text { Inflammation } \\
\text { DNA damage }\end{array}$ \\
\hline $\begin{array}{l}\text { Khymenets et } \\
\text { al., } 2009\end{array}$ & $\begin{array}{l}\mathrm{N}=6 \mathrm{H}(262-28 \text { years; } \\
4 \mathrm{M}(20-44) \\
3 \text { weeks }\end{array}$ & $\mid \mathrm{VOO}(25 \mathrm{ml} /$ day $)$ & $\begin{array}{l}\text { ADAM17, } \\
\text { ALDH1A, BIRC1, } \\
\text { ERCC5, LIAS, } \\
\text { OGT,PPARBP, } \\
\text { TNFSF10, USP48, } \\
\text { XRCC5 }\end{array}$ & $\begin{array}{l}\text { Mechanism involved } \\
\text { in atherosclerosis }\end{array}$ \\
\hline $\begin{array}{l}\text { Camargo et al., } \\
2010\end{array}$ & $\begin{array}{l}\mathrm{N}=20 \text { with } \mathrm{MS} \\
(56 \text { years, } 9 \mathrm{H}, 11 \mathrm{M}) \\
\text { Postprandial state }\end{array}$ & $\begin{array}{l}\text { Breakfast with } \\
\text { VOO }(40 \mathrm{ml}) .\end{array}$ & \begin{tabular}{|l|} 
EGR1 \\
IL1B, IL6 \\
CCL3 \\
CXCL1 \\
CXCL2 \\
CXCL3 \\
CXCR4 \\
TRIB1, NFKBIA \\
\end{tabular} & Inflammation \\
\hline $\begin{array}{l}\text { Llorente-Cortes } \\
\text { et al., } 2009\end{array}$ & $\mathrm{~N}=48$ (55-80 years) & \begin{tabular}{|l|} 
MD+VOO \\
MD+nuts \\
Control group
\end{tabular} & \begin{tabular}{|l|} 
COX-2 \\
LRP1 \\
MCP-1 \\
CD36 \\
TFPI \\
\end{tabular} & $\begin{array}{l}\text { Inflammation, foam } \\
\text { cell formation, } \\
\text { thrombosis }\end{array}$ \\
\hline $\begin{array}{l}\text { De Mello VD } \\
\text { et al., } 2008\end{array}$ & $\begin{array}{l}\text { 34overweight MS } \\
33 \text { weeks }\end{array}$ & $\begin{array}{l}\text { Weight reduction } \\
(\mathrm{n}=24) \\
\text { Control group } \\
(\mathrm{n}=10)\end{array}$ & $\begin{array}{l}\text { TLR4 } \\
\text { TLR2 } \\
\text { CCL5 } \\
\text { TNFRSF1A } \\
\text { IKBKB } \\
\end{array}$ & $\begin{array}{l}\text { Related to insulin } \\
\text { sensitivity }\end{array}$ \\
\hline $\begin{array}{l}\text { Crujeiras et al., } \\
2008\end{array}$ & \begin{tabular}{|l}
12 Obese \\
(37,7 years) \\
8 weeks
\end{tabular} & Hypocaloric diet & \begin{tabular}{|l|} 
SIRT1 \\
SIRT2 \\
NDUFS2
\end{tabular} & \\
\hline
\end{tabular}

MD: Mediterranean diet; VOO: Virgin olive oil; MS: Metabolic Syndrome

Table 3. Nutrigenomics studies 


\section{Conclusions and future directions}

Current results of the studies analyzing the effect of Mediterranean diet on CVD suggest that adherence to the Mediterranean dietary pattern was associated with lower CVD phenotypes. Mediterranean diet has a beneficial effect on abdominal obesity, lipids levels, glucose metabolism, blood pressure and inflammation. The antioxidant and antiinflammatory effects of the Mediterranean diet as a whole, and also the effects of the individual components, specifically VOO, fruits, vegetables, whole grains and fish could offer an explanation for the aforementioned beneficial effects of the Mediterranean diet.

These results are of considerable public health importance because this dietary pattern can be easily adopted by all population groups and various cultures, and they cost effectively serve for the primary and secondary prevention of CVD.

On the other hand, the current evidence from nutrigenetics studies is not enough to begin implementing specific personalized information. However, there is a large number of examples of common SNPs modulating the individual response to Mediterranean diet and other components as proof of concept of how gene-diet interactions can influence lipid metabolism, BMI, or other disorders, and it is expected that in the near future we will be able to harness the information contained in our genomes by using the behavioural tools to achieve successful personalized nutrition. In order to achieve that, it is recommended that future advises on nutrition will be based on studies using the highest level of epidemiological evidence and supported by mechanistic studies within the Nutritional Genomics and Systems biology. However, we have to take into account that in order to forget successful results in personalized nutrition through genetic variation, health professionals need to be prepared to learn and interpret genetic knowledge about their patients.

\section{References}

Alvarez León, EE., Henríquez, P., \& Serra-Majem, L. (2006). Mediterranean diet and metabolic syndrome: a cross-sectional study in the Canary Islands. Public Health Nutr; 9(8A):1089-98.

Ambring, A., Friberg, P., Axelsen, M., Laffrenzen, M., Taskinen, MR., \& Basu, S. (2004). Effects of a Mediterranean-inspired diet on blood lipids, vascular function and oxidative stress in healthy subjects. M Clin Sci; 106(5):519-25.

Andreoli, A., Lauro, S., Di Daniele, N., Sorge, R., Celi, M., \& Volpe, SL. (2008). Effect of a moderately hypoenergetic Mediterranean diet and exercise program on body cell mass and cardiovascular risk factors in obese women. Eur J Clin Nutr;62(7):892-7.

Athyros, VG., Kakafika, AI., Papageorgiou, AA., Tziomalos, K., Peletidou, A., Vosikis, C., Karagiannis, A., \& Mikhailidis, DP. (2011). Effect of a plant stanol ester-containing spread, placebo spread, or Mediterranean diet on estimated cardiovascular risk and lipid, inflammatory and haemostatic factors. Nutr Metab Cardiovasc Dis;21(3):213-21.

Barzi, F., Woodward, M., Marfisi, RM., Tavazzi, L., Valagussa, F., \& Marchioli, R. (2003). Mediterranean diet and all-causes mortality after myocardial infarction: results from the GISSI-Prevenzione trial. Eur J Clin Nutr; 57(4):604-11. 
Bes-Rastrollo, M., Wedick, NM., Martinez-Gonzalez, MA., Li, TY., Sampson, L., \& Hu, FB. (2009). Prospective study of nut consumption, long-term weight change, and obesity risk in women. Am J Clin Nutr; 89(6):1913-9.

Blum, S., Aviram, M., Ben-Amotz, A., \& Levy, Y. (2006). Effect of a Mediterranean meal on postprandial carotenoids, paraoxonase activity and C-reactive protein levels. Ann Nutr Metab; 50(1):20-4.

Brennan, AM., Sweeney, LL., Liu, X., \& Mantzoros, CS. (2010). Walnut consumption increases satiation but has no effect on insulin resistance or the metabolic profile over a 4-day period. Obesity (Silver Spring);18(6):1176-82.

Brennan, RO. (1975) Nutrigenetics: new concepts for relieving hypoglycemia. New York: M. Evans and Co.

Brown, S., Ordovás, JM., Campos, H. (2003) Interaction between the APOC3 gene promoter polymorphisms, saturated fat intake and plasma lipoproteins. Atherosclerosis; 170(2):307-13.

Camargo, A., Ruano, J., Fernandez, JM., Parnell, LD., Jimenez, A., Santos-Gonzalez, M. et al. (2010). Gene expression changes in mononuclear cells in patients with metabolic syndrome after acute intake of phenol-rich virgin olive oil. BMC Genomics; 11:253.

Campos, H., D'Agostino, M., \& Ordovás, JM. (2001). Gene-diet interactions and plasma lipoproteins: role of apolipoprotein $\mathrm{E}$ and habitual saturated fat intake. Genet Epidemiol; 20(1):117-128.

Castro, P., Miranda, JL., Gómez, P., Escalante, DM., Segura, FL., Martín, A., et al. (2000). Comparison of an oleic acid enriched-diet vs NCEP-I diet on LDL susceptibility to oxidative modifications. Eur J Clin Nutr; 54(1):61-7.

Chrysohoou, C., Panagiotakos, DB., Pitsavos, C., Das, UN., \& Stefanadis, C. (2004). Adherence to the Mediterranean diet attenuates inflammation and coagulation process in healthy adults: The ATTICA Study. J Am Coll Cardiol; 44(1):152-8.

Corella, D., Carrasco, P., Sorlí, JV., Coltell, O., Ortega-Azorín, C., Guillén, M., et al. (2010). Education modulates the association of the FTO rs9939609 polymorphism with body mass index and obesity risk in the Mediterranean population. Nutr Metab Cardiovasc Dis. 2010 Dec 24. [Epub ahead of print]

Corella, D., Lai, CQ., Demissie, S., Cupples, LA., Manning, AK., Tucker, KL., \& Ordovas, JM. (2007). APOA5 gene variation modulates the effects of dietary fat intake on body mass index and obesity risk in the Framingham Heart Study. J Mol Med (Berl); 85(2):119-28.

Corella, D., \& Ordovas, JM. (2005). Integration of environment and disease into 'omics' analysis. Curr Opin Mol Ther; 7(6):569-76.

Corella, D., Peloso, G., Arnett, DK., Demissie, S., Cupples, LA., Tucker, K., et al. (2009). APOA2, dietary fat, and body mass index: replication of a gene-diet interaction in 3 independent populations. Arch Intern Med; 169(20):1897-906.

Corella, D., Tai, ES., Sorlí, JV., Chew, SK., Coltell, O., Sotos-Prieto, M., et al. (2011). Association between the APOA2 promoter polymorphism and body weight in Mediterranean and Asian populations: replication of a gene-saturated fat interaction. Int J Obes (Lond); 35(5):666-75.

Corella, D., Tucker, K., Lahoz, C., Coltell, O., Cupples, LA., Wilson, et al. (2001). Alcohol drinking determines the effect of the APOE locus on LDL-cholesterol 
concentrations in men: the Framingham Offspring Study. Am J Clin Nutr; 73(4):73645.

Crujeiras, AB., Parra, D., Goyenechea, E., Abete, I., González-Muniesa, P., \& Martínez, JA. (2008). Energy restriction in obese subjects impact differently two mitochondrial function markers. J Physiol Biochem; 64(3):211-9.

de Lorgeril, M., Renaud, S., Mamelle, N., Salen, P., Martin, JL., Monjaud, I., et al. (1994). Mediterranean alpha-linolenic acid-rich diet in secondary prevention of coronary heart disease. Lancet; 343(8911):1454-9.

de Lorgeril, M., Salen, P., Martin, JL., Monjaud, I., Delaye, J., \& Mamelle, N. (1999). Mediterranean diet, traditional risk factors, and the rate of cardiovascular complications after myocardial infarction: final report of the Lyon Diet Heart Study. Circulation; 99(6):779-85.

de Mello, VD., Kolehmainen, M., Pulkkinen, L., Schwab, U., Mager, U., Laaksonen, DE., et al. (2008). Downregulation of genes involved in NFkappaB activation in peripheral blood mononuclear cells after weight loss is associated with the improvement of insulin sensitivity in individuals with the metabolic syndrome: the GENOBIN study. Diabetologia; 51(11):2060-7

DellaPenna, D. 1999. Nutricional genomics: manipulating plant micronutrients to improve human health. Science; 285:375-79

Elhayany, A., Lustman, A., Abel, R., Attal-Singer, J., \& Vinker, S. (2010). A low carbohydrate Mediterranean diet improves cardiovascular risk factors and diabetes control among overweight patients with type 2 diabetes mellitus: a 1-year prospective randomized intervention study. Diabetes Obes Metab;12(3):204-9.

Esposito, K., Kastorini, CM., Panagiotakos, DB., \& Giugliano, D. (2011). Mediterranean diet and weight loss: meta-analysis of randomized controlled trials . Metab Syndr Relat Disord; 9(1):1-12.

Esposito, K., Maiorino, MI., Di Palo, C., Giugliano, D., \& Campanian. (2009). Postprandial Hyperglycemia Study Group. Adherence to a Mediterranean diet and glycaemic control in Type 2 diabetes mellitus. Diabet Med; 26(9):900-7.

Esposito, K., Marfella, R., Ciotola, M., Di Palo, C., Giugliano, F., Giugliano, G., et al. (2004) Effect of a mediterranean-style diet on endothelial dysfunction and markers of vascular inflammation in the metabolic syndrome: a randomized trial. JAMA; 292(12):1440-6.

Esposito, K., Pontillo, A., Di Palo, C., Giugliano, G., Masella, M., Marfella, R., \& Giugliano, D. (2003). Effect of weight loss and lifestyle changes on vascular inflammatory markers in obese women: a randomized trial. JAMA; 289(14):1799-804.

Estruch, R., Martínez-González, MA., Corella, D., Salas-Salvadó, J., Ruiz-Gutiérrez, V., Covas, MI., et al, (2006). Effects of a Mediterranean-style diet on cardiovascular risk factors: a randomized trial. Ann Intern Med;145(1):1-11.

Fraser, GE., Bennett, HW., Jaceldo, KB., \& Sabaté, J. (2002). Effect on body weight of a free 76 Kilojoule (320 calorie) daily supplement of almonds for six months. J Am Coll Nut; 21(3):275-83.

Fung, TT., McCullough, ML., Newby, PK., Manson, JE., Meigs, JB., Rifai, N., et al. (2005). Diet-quality scores and plasma concentrations of markers of inflammation and endothelial dysfunction. Am J Clin Nutr; 82(1):163-73. 
García-Lorda, P., Megias Rangil, I., \& Salas-Salvadó, J. (2003). Nut consumption, body weight and insulin resistance. Eur J Clin Nutr; 57 Suppl 1:S8-11.

Giuseppe, RD., Bonanni, A., Olivieri, M., Castelnuovo, AD., Donati, MB., Gaetano, GD., et al. (2008). Adherence to Mediterranena diet and anthropometric and metabolic parameters in an observational study in the "Alto Molise" region: The MOLI-SAL project. Nutr Metab Cardiovasc Dis; 18(6):415-21.

Goulet, J., Lamarche, B., Nadeau, G., \& Lemieux, S. (2003). Effect of a nutritional intervention promoting the Mediterranean food pattern on plasma lipids, lipoproteins and body eight in healthy French-Canadian women. Atherosclerosis; 170(1):115-24.

Harris, RP., Helfand, M., Woolf, SH., Lohr, KN., Mulrow, CD., Teutsch, SM., et al. (2001). Third U.S. Preventive Services Task Force. Current methods of the U.S. Preventive Services Task Force: a review of the process. Am J Prev Med; 20(3S):21-35.

Haskell, WL. (2003). Cardiovascular disease prevention and lifestyle interventions: effectiveness and efficacy. J Cardiovasc Nurs; 18:245-55

Howard, BV., Van Horn, L., Hsia, J., Manson, JE., Stefanick, ML., Wassertheil-Smoller, S., Kuller, LH., et al. (2006). Low-fat dietary pattern and risk of cardiovascular disease: the Women's Health Initiative Randomized Controlled Dietary Modification Trial. JAMA; 295(6):655-66.

Jansen, S., Lopez-Miranda, J., Salas, J., Ordovas, JM., Castro, P., Marin, C., et al. (1997). Effect of 347-serine mutation in apoprotein A-IV on plasma LDL cholesterol response to dietary fat. Arterioscler Thromb Vasc Biol; 17(8):1532-8.

Kastorini, CM., Milionis, HJ., Esposito, K., Giugliano, D., Goudevenos, JA., \& Panagiotakos, DB. (2011). The effect of Mediterranean diet on metabolic syndrome and its components: a meta-analysis of 50 studies and 534,906 individuals. J Am Coll Cardiol; 57(11):1299-313.

Katan MB, Beynen AC, de Vries JH, Nobels A. (1986). Existence of consistent hypo- and hyperresponders to dietary cholesterol in man. Am J Epidemiol; 123(2):221-34.

Keys, A. (1970). Coronary Heart Disease in Seven Countries. Circulation; 41(1):1-211.

Keys, A., Menotti, A., \& Karoven, MI. (1986). The diet and the 15-year death rate in the Seven Countries Study. Am J Epidemiol; 124:903-915.

Khymenets, O., Fitó, M., Covas, MI., Farré, M., Pujadas, MA., Muñoz, D., Konstantinidou, V., \& de la Torre, R. (2009). Mononuclear cell transcriptome response after sustained virgin olive oil consumption in humans: an exploratory nutrigenomics study. OMICS; 13(1):7-19

Knoops, KT., de Groot, LC., Kromhout, D., Perrin, AE., Moreiras-Varela, O., Menotti, A., et al. (2004). Mediterranean diet, lifestyle factors, and 10-year mortality in elderly European men and women: the HALE project. JAMA; 292(12):1433-9.

Konstantinidou, V., Covas, MI., Muñoz-Aguayo, D., Khymenets, O., de la Torre, R., Saez, G., et al. (2010). In vivo nutrigenomic effects of virgin olive oil polyphenols within the frame of the Mediterranean diet: a randomized controlled trial. FASEB J; 24(7):254657.

Konstantinidou, V., Khymenets, O., Fito, M., De La Torre, R., Anglada, R., Dopazo, A., \& Covas, MI. (2009). Characterization of human gene expression changes after olive oil ingestion: an exploratory approach. Folia Biol (Praha); 55(3):85-91 
Krauss, RM., Eckel, RH., Howard, B., Appel, LJ., Daniels, SR., \& Deckelbaum, RJ. (2000). AHA Dietary Guidelines: revision 2000: A statement for healthcare professionals from the Nutrition Committee of the American Heart Association. Stroke; 31(11):2751-66.

Lalonde, M. (1974). A new perspective on the health of canadians: a working document. Ottawa: Department of Health and Welfare.

Larsen, TM., Dalskov, SM., van Baak, M., Jebb, SA., Papadaki, A., Pfeiffer, AF., et al. (2010). Diet, Obesity, and Genes (Diogenes) Project. Diets with high or low protein content and glycemic index for weight-loss maintenance. N Engl J Med; 363(22):2102-13.

Li, Z., Song, R., Nguyen, C., Zerlin, A., Karp, H., Naowamondhol, K., et al. (2010). Pistachio nuts reduce triglycerides and body weight by comparison to refined carbohydrate snack in obese subjects on a 12-week weight loss program. J Am Coll Nutr; 29(3):198-203.

Lichtenstein, AH., Ausman, LM., Jalbert, SM., Vilella-Bach, M., Jauhiainen, M., McGladdery, S., et al. (2002). Efficacy of a Therapeutic Lifestyle Change/Step 2 diet in moderately hypercholesterolemic middle-aged and elderly female and male subjects. J Lipid Res;43(2):264-73.

Linton MF, Fazio S, National Cholesterol Education Program (NCEP)- the third Adult Treatment Panel (ATP III). (2003). A practical approach to risk assessment to prevent coronary artery disease and its complications. Am J Cardiol; 92(1A):19i-26i.

Llorente-Cortés V, Estruch R, Mena MP, Ros E, González MA, Fitó M, et al. (2010). Effect of Mediterranean diet on the expression of pro-atherogenic genes in a population at high cardiovascular risk. . Atherosclerosis; 208(2):442-50

Loktionov, A. (2003) Common gene polymorphisms and nutrition: emerging links with pathogenesis of multifactorial chronic diseases (review). J Nutr Biochem;14(8):42651.

Lopez-Miranda J, Ordovas JM, Mata P, Lichtenstein AH, Clevidence B, Judd JT, Schaefer EJ. (1994). Effect of apolipoprotein E phenotype on diet-induced lowering of plasma low density lipoprotein cholesterol. J Lipid Res; 35(11):1965-75.

Luan, J., Browne, PO., Harding, AH., Halsall, DJ., O'Rahilly, S., Chatterjee, VK., \& Wareham NJ. (2001). Evidence for gene-nutrient interaction at the PPARgamma locus. Diabetes; 50(3):686-9.

Martínez-González, MA., \& Bes-Rastrollo, M. (2011). Nut consumption, weight gain and obesity: Epidemiological evidence. Nutr Metab Cardiovasc Dis;21 Suppl 1:S40-5.

Martínez-González, MA., Fuente-Arrillaga, CD., Nunez-Cordoba, JM., Basterra-Gortari, FJ., Beunza, JJ., Vazquez, Z., et al. (2008). Adherence to Mediterranean diet and risk of developing diabetes: prospective cohort study. BMJ; 336(7657):1348-51.

Masala, G., Bendinelli, B., Versari, D., Saieva, C., Ceroti, M., Santagiuliana, F., et al. (2008). Anthropometric and dietary determinants of blood pressure in over 7000 Mediterranean women: the European Prospective Investigation into Cancer and Nutrition-Florence cohort. J Hypertens; 26(11):2112-20.

Masson, LF., McNeill, G., \& Avenell, A. (2003). Genetic variation and the lipid response to dietary intervention: a systematic review. Am J Clin Nutr; 77(5):1098-111.

Memisoglu, A., Hu, FB., Hankinson, SE., Manson, JE., De Vivo, I., Willett, WC., \& Hunter, DJ. (2003). Interaction between a peroxisome proliferator-activated receptor gamma 
gene polymorphism and dietary fat intake in relation to body mass. Hum Mol Genet; 12(22):2923-9.

Michalsen, A., Lehmann, N., Pithan, C., Knoblauch, NT., Moebus, S., Kannenberg, F., et al. (2006). Mediterranean diet has no effect on markers of inflammation and metabolic risk factors in patients with coronary artery disease. Eur J Clin Nutr; 60(4):478-85.

Müller-Nordhorn, J., Rossnagel, K., Mey, W., \& Willich, SN. (2004). Regional variation and time trends in mortality from ischaemic heart disease: East and West Germany 10 years after reunification. J Epidemiol Community Health; 58:481-485.

Núñez-Córdoba, JM., Valencia-Serrano, F., Toledo, E., Alonso, A., \& Martínez-González, MA. (2009). The Mediterranean diet and incidence of hypertension: the Seguimiento Universidad de Navarra (SUN) Study. Am J Epidemiol; 169(3):339-46.

Obarzanek, E., Sacks, FM., Vollmer, WM., Bray, GA., Miller, ER3rd., Lin, PH., et al. DASH Research Group. (2001). Effects on blood lipids of a blood pressure-lowering diet: the Dietary Approaches to Stop Hypertension (DASH) Trial. Am J Clin Nutr; 74(1):80-9.

Ordovas, JM., Corella, D., Demissie, S., Cupples, LA., Couture, P., Coltell, O., et al. (2001). Dietary fat intake determines the effect of a common polymorphism in the hepatic lipase gene promoter on high-density lipoprotein metabolism: evidence of a strong dose effect in this gene-nutrient interaction in the Framingham Study. Circulation;106(18):2315-21.

Ordovas, JM., \& Corella, D. (2004). Nutritional genomics. Annu Rev Genomics Hum Genet; 5:71-118

Ordovas JM, Mooser V. (2004). Nutrigenomics and nutrigenetics. Curr Opin Lipidol; 15(2):101-8.

Panagiotakos, DB., Pitsavos, C., Arvaniti, F., \& Stefanadis, C. (2007). Adherence to the Mediterranean food pattern predicts the prevalence of hypertension, hypercholesterolemia, diabetes and obesity, among healthy adults; the accuracy of the MedDietScore. Prev Med; 44(4):335-40.

Panagiotakos, DB., Pitsavos, C., \& Stefanadis, C. (2006). Dietary patterns: a Mediterranean diet score and its relation to clinical and biological markers of cardiovascular disease risk. Nutr Metab Cardiovasc Dis; 16(8):559-68.

Panagiotakos, DB., Tzima, N., Pitsavos, C., Chrysohoou, C., Zampelas, A., Toussoulis, D., et al. (2007). The association between adherence to the Mediterranean diet and fasting indices of glucose homoeostasis: the ATTICA Study. J Am Coll Nutr; 26(1):32-8.

Panagiotou, G., Nielsen J. (2009). Nutritional systems biology: definitions and approaches. Annu Rev Nutr; 29:329-39.

Papadaki, A., Scott JA. (2008). Follow-up of a web-based tailored intervention promoting the Mediterranean diet in Scotland. Patient Educ Couns; 73(2):256-63.

Pérez-Martínez, P., Pérez-Jiménez, F., Bellido, C., Ordovás, JM., Moreno, JA., Marín, C., et al. (2005). A polymorphism exon 1 variant at the locus of the scavenger receptor class B type I (SCARB1) gene is associated with differences in insulin sensitivity in healthy people during the consumption of an olive oil-rich diet. J Clin Endocrinol Metab; 90(4):2297-300.

Pitsavos, C., Panagiotakos, D., Trichopoulou, A., Chrysohoou, C., Dedoussis, G., Chloptsios, Y., et al. (2006). Interaction between Mediterranean diet and methylenetetrahydrofolate reductase C677T mutation on oxidized low density 
lipoprotein concentrations: the ATTICA study. Nutr Metab Cardiovasc Dis; 16(2):919.

Pitsavos, C., Panagiotakos, DB., Chrysohoou, C., \& Stefanadis, C. (2003). Epidemiology of cardiovascular risk factors in Greece: aims, design and baseline characteristics of the ATTICA study. BMC Public Health; 3:32-40.

Pitsavos, C., Panagiotakos, DB., Tzima, N., Lentzas, Y., Chrysohoou, C., Das, UN-, et al. (2007). Diet, exercise, and C-reactive protein levels in people with abdominal obesity: the ATTICA epidemiological study. Angiology;58(2):225-33.

Polychronopoulos, E., Panagiotakos, DB., Polystipioti. (2005). A.Diet, lifestyle factors and hypercholesterolemia in elderly men and women from Cyprus. Lipids Health Dis; 6;4:17

Posner, BM., Cobb, JL., Belanger, AJ., et al. (1991). Dietary lipid predictors of coronary heart disease in men. The Framingham Study. Arch Intern Med; 151:1181-7.

Psaltopoulou, T., Naska, A., Orfanos, P., Trichopoulos, D., Mountokalakis, T., Trichopoulou, A. (2004). Olive oil, the Mediterranean diet, and arterial blood pressure: the Greek European Prospective Investigation into Cancer and Nutrition (EPIC) study. Am J Clin Nutr;80(4):1012-8.

Rajaram, S., \& Sabaté, J. Nuts, body weight and insulin resistance. Br J Nutr. 2006;96 Suppl 2:S79-86.

Razquin, C., Martinez, JA., Martinez-Gonzalez, MA., Bes-Rastrollo, M., Fernández-Crehuet, \& J., Marti, A. (2010 A). A 3-year intervention with a Mediterranean diet modified the association between the rs9939609 gene variant in FTO and body weight changes. Int J Obes (Lond); 34(2):266-72.

Razquin, C., Martinez, JA., Martinez-Gonzalez, MA., Fernández-Crehuet, J., Santos, JM., \& Marti, A. (2010 B). A Mediterranean diet rich in virgin olive oil may reverse the effects of the $-174 \mathrm{G} / \mathrm{C}$ IL6 gene variant on 3-year body weight change. Mol Nutr Food Res;54 Suppl 1:S75-82.

Razquin, C., Martínez, JA., Martínez-González, MA., Salas-Salvadó. J-, Estruch, R., \& Marti, A. (2010 C). A 3-year Mediterranean-style dietary intervention may modulate the association between adiponectin gene variants and body weight change. Eur J Nutr; 49(5):311-9.

Robitaille, J., Pérusse, L., Bouchard, C., \& Vohl, MC. (2007). Genes, fat intake, and cardiovascular disease risk factors in the Quebec Family Study. Obesity (Silver Spring);15(9):2336-47.

Romaguera, D., Norat, T., Vergnaud, AC., Mouw, T., May, AM., Agudo, A., et al. (2010). Mediterranean dietary patterns and prospective weight change in participants of the EPIC-PANACEA project. Am J Clin Nutr; 92(4):912-21.

Ros, E., Núñez, I., Pérez-Heras, A., Serra, M., Gilabert, R., Casals, E., et al. (2004). A walnut diet improves endothelial function in hypercholesterolemic subjects: a randomized crossover trial. Circulation; 109(13):1609-14.

Sabaté, J., Oda, K., \& Ros, E. (2010). Nut consumption and blood lipid levels: a pooled analysis of 25 intervention trials. Arch Intern Med; 170(9):821-7.

Sacks, FM., Bray, GA., Carey, VJ., Smith, SR., Ryan, DH., Anton, SD., et al. (2009). Comparison of weight-loss diets with different compositions of fat, protein, and carbohydrates. N Engl J Med; 360(9):859-73. 
Salas-Salvadó, J., Bulló, M., Babio, N., Martínez-González, MÁ., Ibarrola-Jurado, N., Basora, J., et al. PREDIMED Study Investigators. (2011). Reduction in the incidence of type 2 diabetes with the Mediterranean diet: results of the PREDIMED-Reus nutrition intervention randomized trial. Diabetes Care; 34(1):14-9.

Salas-Salvadó, J., Garcia-Arellano, A., Estruch, R., Marquez-Sandovalm F., Corellam D., Fiol, M., et al. (2008). Components of the mediterranean-type food pattern and serum inflammatory markers among patients at high risk for cardiovascular disease. Eur J Clin Nutr, 62(5):651-9.

Sans, S., Kesteloot, H., \& Kromhout, D. (1997). The burden of cardiovascular diseases mortality in Europe. Task Force of the European Society of Cardiology on Cardiovascular Mortality and Morbidity Statistics in Europe. Eur Heart J; 18:12311248.

Schröder, H., Marrugat, J., Vila, J., Covas, MI., \& Elosua, R. (2004). Adherence to the traditional mediterranean diet is inversely associated with body mass index and obesity in a Spanish population. J Nutr; 134(12):3355-61.

Schröder H. (2007). Protective mechanisms of the Mediterranean diet in obesity and type 2 diabetes. J Nutr Biochem; 18(3):149-60.

Serra-Majem, L., Trichopoulou, A., Ngo de la Cruz, J., Cervera, P., García Alvarez, A., La Vecchia, C., et al. (2004). Does the definition of the Mediterranean diet need to be updated? Public Health Nutr; 7(7):927-9.

Serrano-Martínez M, Martínez-González MA. (2007). Effects of Mediterranean diets on plasma biomarkers of inflammation. Eur J Clin Nutr; 61(8):1035-6; author reply 1036.

Shai, I., Schwarzfuchs, D., Henkin, Y., Shahar, DR., Witkow, S., \& Greenberg, I.; Dietary Intervention Randomized Controlled Trial (DIRECT) Group. (2008). Weight loss with a low-carbohydrate, Mediterranean, or low-fat diet. N Engl J Med; 359(3):22941.

Singh, RB., Dubnov, G., Niaz, MA., Ghosh, S., Singh, R., Rastogi, SS., et al. (2002). Effect of an Indo-Mediterranean diet on progression of coronary artery disease in high risk patients (Indo-Mediterranean Diet Heart Study): a randomised single-blind trial. The Lancet; 360(9344):1455-61.

Slimani, N., Kaaks, R., Ferrari, P., Casagrande, C., Clavel-Chapelon, F., Lotze, G., et al. (2002). European Prospective Investigation into Cancer and Nutrition (EPIC) calibration study: rationale, design and population characteristics. Public Health Nutr; 5(6B):1125-45.

Smith, CE., Arnett, DK., Corella, D., Tsai, MY., Lai, CQ., Parnell, LD., et al. (2010). Perilipin polymorphism interacts with saturated fat and carbohydrates to modulate insulin resistance. Nutr Metab Cardiovasc Dis. 2010 Dec 30. [Epub ahead of print].

Sotos-Prieto, M., Zulet, MA., \& Corella, D. (2010). Scientific evidence of the mediterranean diet effects in determining intermediate and final cardiovascular disease phenotypes. Med Clin (Barc);134(1):22-9

Tai, ES., Collins, D., Robins, SJ., O'Connor, JJ., Bloomfield, HE., Ordovas, JM., et al. (2006). The L162V polymorphism at the peroxisome proliferator activated receptor alpha locus modulates the risk of cardiovascular events associated with insulin resistance and diabetes mellitus: the Veterans Affairs HDL Intervention Trial (VA-HIT). Atherosclerosis; 187(1):153-60. 
Trichopoulou, A., Costacou, T., Bamia, C., \& Trichopoulous, D. (2003). Adherente to a Mediterranean diet and survival in a Greek population. N Eng J Med; 348:2599-2608.

Tzima, N., Pitsavos, C., Panagiotakos, DB., Skoumas, J., Zampelas, A., Chrysohoou, C., et al. (2007). Mediterranean diet and insulin sensitivity, lipid profile and blood pressure levels, in overweight and obese people; the Attica study. Lipids Health Dis; 6:22.

Vincent-Baudry, S., Defoort, C., Gerber, M., Bernard, MC., Verger, P., Helal, O., et al. (2005). The Medi-RIVAGE study: reduction of cardiovascular disease risk factors after a 3mo intervention with a Mediterranean-type diet or a low-fat diet. Am J Clin Nutr; 82(5):964-71. 


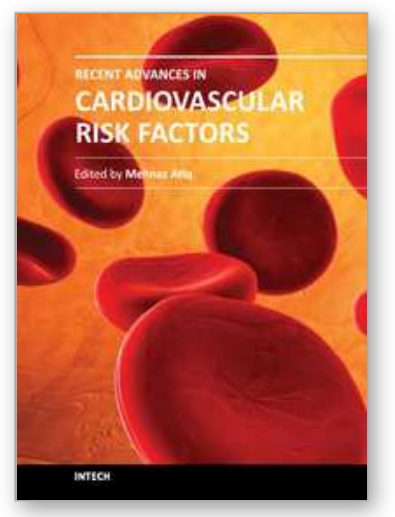

\author{
Recent Advances in Cardiovascular Risk Factors \\ Edited by Prof. Mehnaz Atiq
}

ISBN 978-953-51-0321-9

Hard cover, 522 pages

Publisher InTech

Published online 21, March, 2012

Published in print edition March, 2012

Among the non-communicable diseases, cardiovascular disorders are the leading cause of morbidity and mortality in both the developed and the developing countries. The spectrum of risk factors is wide and their understanding is imperative to prevent the first and recurrent episodes of myocardial infarction, stroke or peripheral vascular disease which may prove fatal or disabling. This book has tried to present an update on risk factors incorporating new research which has thrown more light on the existing knowledge. It has also tried to highlight regional diversity addressing such issues. It will hopefully be resourceful to the cardiologists, general practitioners, family physicians, researchers, graduate students committed to cardiovascular risk prevention.

\title{
How to reference
}

In order to correctly reference this scholarly work, feel free to copy and paste the following:

Mercedes Sotos Prieto (2012). Mediterranean Diet and Gene-Mediterranean Diet Interactions in Determining Intermediate Cardiovascular Disease Phenotypes, Recent Advances in Cardiovascular Risk Factors, Prof. Mehnaz Atiq (Ed.), ISBN: 978-953-51-0321-9, InTech, Available from:

http://www.intechopen.com/books/recent-advances-in-cardiovascular-risk-factors/mediterranean-diet-andgene-mediterranean-diet-interactions-in-determining-intermediate-cardiovascul

\section{INTECH}

open science | open minds

\author{
InTech Europe \\ University Campus STeP Ri \\ Slavka Krautzeka 83/A \\ 51000 Rijeka, Croatia \\ Phone: +385 (51) 770447 \\ Fax: +385 (51) 686166 \\ www.intechopen.com
}

\author{
InTech China \\ Unit 405, Office Block, Hotel Equatorial Shanghai \\ No.65, Yan An Road (West), Shanghai, 200040, China \\ 中国上海市延安西路65号上海国际贵都大饭店办公楼 405 单元 \\ Phone: +86-21-62489820 \\ Fax: +86-21-62489821
}


(C) 2012 The Author(s). Licensee IntechOpen. This is an open access article distributed under the terms of the Creative Commons Attribution 3.0 License, which permits unrestricted use, distribution, and reproduction in any medium, provided the original work is properly cited. 